\title{
EFFECT OF MACHINE FEED RATE ON KERF-WIDTH, MATERIAL REMOVAL RATE, AND SURFACE ROUGHNESS IN MACHINING OF AL/SIC COMPOSITE MATERIAL WITH WIRE ELECTRICAL DISCHARGE MACHINE
}

\author{
MANOJ Modi ${ }^{1}$, GOPAL Agarwal' ${ }^{2}$, SWATI D Chaugaonkar ${ }^{3}$, \\ UMESH Bhatia ${ }^{4}$, VEERENDRA Patil ${ }^{5}$ \\ ${ }^{1}$ Department of Mechanical Engineering, Acropolis Institute of Technology and Research, Indore, India. \\ e - mail: manojmnitjaipur1@gmail.com \\ ${ }^{2}$ Department of Mechanical Engineering, Malaviya National Institute of Technology, Jaipur, \\ Rajasthan, India, e - mail: agrawal.drg@gmail.com \\ ${ }^{3}$ Department of Mechanical Engineering, Shri Govindram Seksaria Institute of Technology and Science, \\ Indore, Madhya Pradesh, India, e - mail: swati18may@yahoo.co.in \\ ${ }^{4,5}$ Department of Mechanical Engineering, Acropolis Institute of Technology and Research, Indore, India.
}

\begin{abstract}
The impact of machine feed rates of Wire Electric Discharge Machining on the kerf-width (K-width), material-removal-rate (MR-R), and surface-roughness (S-R) in the machining of $\mathrm{Al} / \mathrm{SiC}$ composite is practically analysed. The relation among the feed rates of machine and K-width, MR-R, S-R is graphically acquired. It is demonstrated that lesser rate of feed is responsible for generation of larger K-width, lesser MR-R, and good finish as compared to more feed rate.
\end{abstract}

Keywords: Wire Electrical Discharge Machine, Kerf-width, Material removal rate, Surface roughness, Machine feed rate, $\mathrm{Al} / \mathrm{SiC}$ composite material etc.

\section{Introduction}

Wire Electrical Discharge Machine (W-EDM) is generally utilized in the manufacturing of smaller components of complex shape. Material is disintegrated by discrete discharge of sparks among the wok-piece and brass wire. These sparks releases liquefy and vaporize little measures of the work-material. These eroded materials from work-piece are flushed out by the dielectric-fluid. In W-EDM, the work-piece and the brass wire don't have contact; only conductive material can be machined [1].

In the production of such components by W-EDM, one of the significant attributes is the kerf-width (K-width) formed by the brass wire electrode. As displayed in Fig. 1, the K-width $(\delta)$ is the summation of the brass wire diameter (d), and double gap-spark $(\Delta)$. In W-EDM, material is dissolved from the composite material workpiece by a progression of discrete flashes happening between the composite material and the wire isolated by a stream of dielectric liquid, which is ceaselessly moved to the machining zone. The procedure utilizes a fine brass wire as the anode and the composite material is mounted on a PC numericcontrolled (CNC) positioning system.

Parameters' influencing the K-width in W-EDM is the properties of the working liquid and the properties of the material of work-piece, as mentioned in [1, 2]. In W-EDM, the K-width is the primary determinative factor of the machining exactness. The few scientists, $[3,4,5]$ examined on the different features of the advancements of Electrical Discharge Machining (ED-M) research. These features are optimization of process-factors, enhancement in process 
effectiveness, simplify design of electrode and fabricate, spark mechanism and its control, and enhancement in surface finish of W-EDM process, etc. De et al. [6] performed the tests on WEDM with sintered Ti (titanium). They contemplated the impact of different parameters i.e., $\mathrm{T}_{\text {on }}$ (pulse on time), $\mathrm{T}_{\text {off }}$ (pulse off time), wire-feed, and wire-tension on material removal rate (MR-R), surface roughness (S-R), K-width, and over-cut. They utilized Response Surface Methodology (RS-M) for the evolution of model of the responses. Raturi et al. [7] conducted the tests on W-EDM with $\mathrm{Al} 6063 / \mathrm{SiC} / \mathrm{Al}_{2} \mathrm{O}_{3}$ composite. They revealed that the MR-R and S$\mathrm{R}$ enhance with increment in \% weight division of $\mathrm{SiC}$ and $\mathrm{Al}_{2} \mathrm{O}_{3}$ particles in Metal Matrix Composites (M-MCs), and Hybrid Metal Matrix Composites (HM-MCs).

The numerous investigators reported that the machining of composite material with $\mathrm{W}$ EDM, the K-width enhanced fundamentally by the variation of procedure factors $[8,9]$. The impact of procedure factors on MR-R was studied on M-MC of Al 6063 with W-EDM. It was studied that the rise in volume percentage of $\mathrm{SiC}$ brought about diminished MR-R [10]. Surface roughness rises with the increment in SiC particles volume percentage in the M-MCs [11]. Modi et al. [12] reported about the study of W-EDM process and its various process parameters. Modi et al. [13] did the experiments on EDDSG process with Inconel 600. They reported in this research work about the modelling of process parameter by RS-M and parametric optimization through Grey-WPCA (Weighted Principle Component Analysis) approach.

The examination of input procedure factor like $\mathrm{O}_{2}$ gas, utilized as dielectric fluid, in the dry W-EDM process was conducted. They noticed a critical impact on the cutting speed, and surface [14]. Madhavadev et al. (2018) studied the formulation of a numerical model dependent on the working conditions and its comparison with the analytical-model to anticipate the deflection of wire in Wire-Electrical Discharge Grinding (W-EDG). In this work Finite-Element Analysis (F-EA) for the deflection of wire is investigated and compared with the analytical-model. Gauri et al. (2010) utilized Grey Relational Analysis (GRA), Multiple Response signal-to-noise Ratio (MRSNR), Weighted signal-to-noise (WSNR), and VlseKriterijumska Optimizacija I Kompromisno Resenje (VIKOR) methods in multi-response optimization on the data's with W-EDM. They also reported the comparative performance of these methodologies. Phate et al. (2019) conducted the experiments on W-EDM with Al/SiC composite and determine the optimum set of procedure parameters by Taguchi based GreyFuzzy methodology. Similarly, the various hybrid/Taguchi methodologies have been applied in various research articles for determination of optimum process factors either in non conventional hybrid process or in conventional process [18-22].

Based on the literature review, the impact of machine feed rate (MF-R) on kerf width, MR$\mathrm{R}$, and $\mathrm{S}-\mathrm{R}$ in W-EDM of $\mathrm{Al} / \mathrm{SiC}$ composite material is the area under development.

The aim of this work is to thoroughly investigate the impact of machine feed rate on kerf width, MR-R, and S-R in W-EDM of Al/SiC composite material. To fulfil this aims, one set of 4 experiments with $\mathrm{Al} / \mathrm{SiC}$ composite material were conducted on W-EDM. Further, kerfwidth images investigation has been conducted on produced machine surfaces through WEDM process. This is also another area under development.

\section{Experimental materials and methods}

This paper utilizes terminology given in Appendix A.

The $\mathrm{Al} / \mathrm{SiC}$ composite material workpiece of size ( $30 \mathrm{~mm} \times 25 \mathrm{~mm} \times 20 \mathrm{~mm}$ ) is machined on W-EDM. The composition of $\mathrm{Al} / \mathrm{SiC}$ composite material is $\mathrm{Al}=85 \%$, and $\mathrm{SiC}=15 \%$. In this experimental work brass wire of diameter $0.25 \mathrm{~mm}$ is used as an electrode. The deionised water is used as a dielectric fluid. 
Figure 1 display the K-width is the summation of wire diameter (d), and the double spark$\operatorname{gap}(\Delta)$.

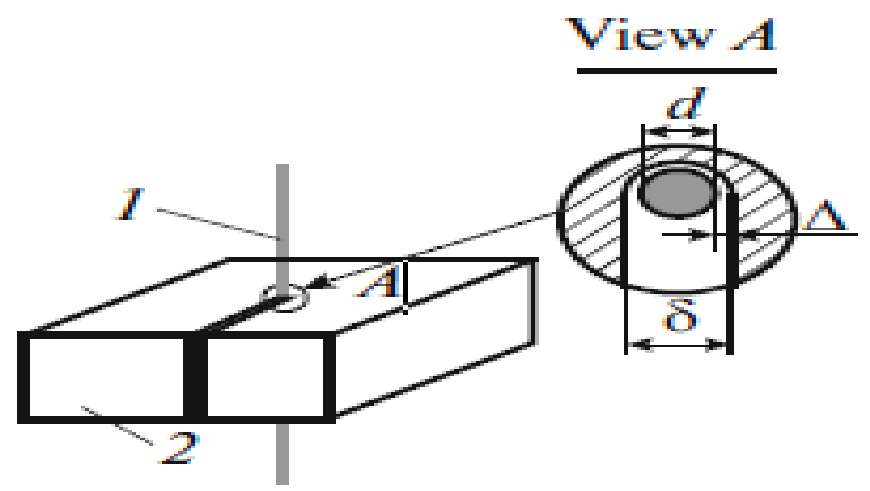

Fig.1 Formation of K-width ( $\delta$ ): (1) wire electrode; (2) work-piece of composite material

The various input parameters levels and the output responses are displayed in Table 1. In these tests, the levels of input parameters have been chosen after the conduction of pilot tests. In these experimental work, the value of input parameters i.e. current $=5$ ampere, Wire-Speed $=5 \mathrm{~m} / \mathrm{min}$., Wire-Tension $=1.3 \mathrm{Kg}$, and Voltage $=60$ Volts were remains the same except the machining feed rate. The Wensar electronic balance was used with readability of $1 \mathrm{mg}$ for the measurement of weight of workpiece before and after the machining. The Surtronic-25, SR analyzer at a cut-off value of $0.8 \mathrm{~mm}$ was utilized for the measurement of S-R.

Table1: W-EDM input parameters and responses

\begin{tabular}{|c|c|c|c|c|}
\hline $\begin{array}{c}\text { S. } \\
\text { No. }\end{array}$ & $\begin{array}{c}\text { Machining Feed-Rate } \\
(\mathrm{mm} / \mathrm{min} .)\end{array}$ & $\begin{array}{c}\text { K-Width }(\delta) \\
(\mathrm{mm})\end{array}$ & $\begin{array}{c}\text { MR-R } \\
\left(\mathrm{mm}^{3} / \mathrm{min}\right)\end{array}$ & $\begin{array}{c}\text { S-R } \\
(\mu \mathrm{m})\end{array}$ \\
\hline 1 & 3 & 0.342 & 3.81 & 1.38 \\
\hline 2 & 6 & 0.339 & 7.52 & 1.41 \\
\hline 3 & 9 & 0.338 & 10.83 & 1.45 \\
\hline 4 & 12 & 0.334 & 13.81 & 1.48 \\
\hline
\end{tabular}

Nikon optiphot microscope at 100 magnifications has been used to measure the K-width of machined work-piece. The K-width $(\delta)$ is analysed on an image analyser at 100 magnifications. Fig. 2 demonstrates the microscope images of machined work-piece for the K-width.
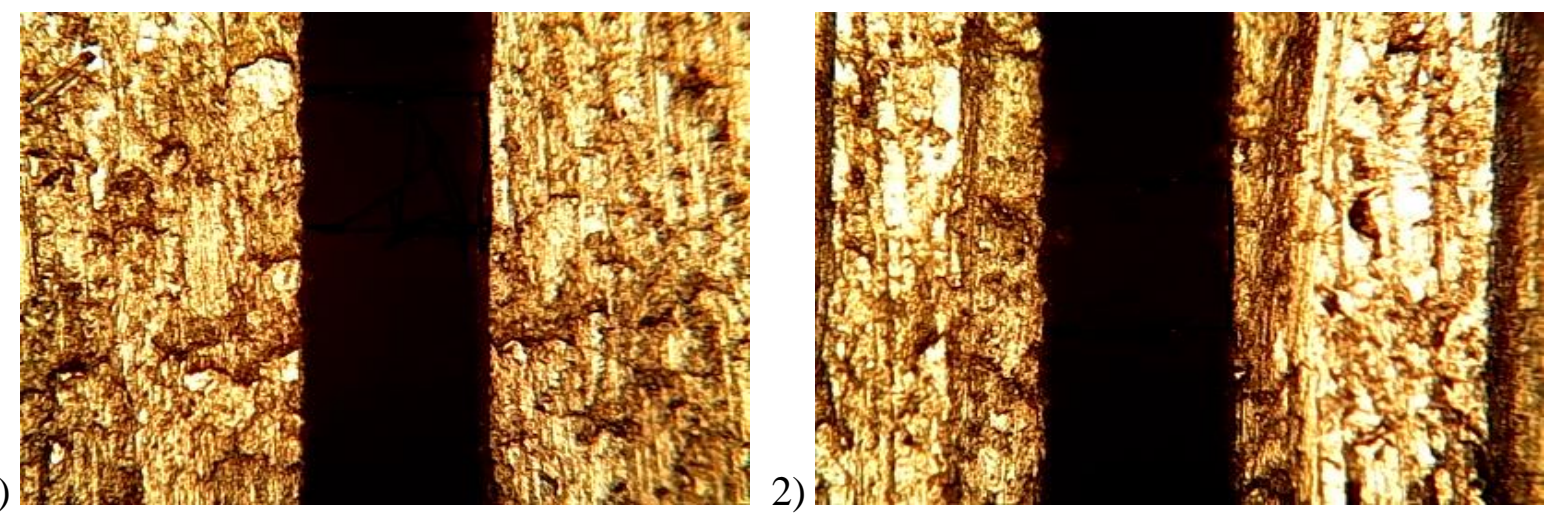

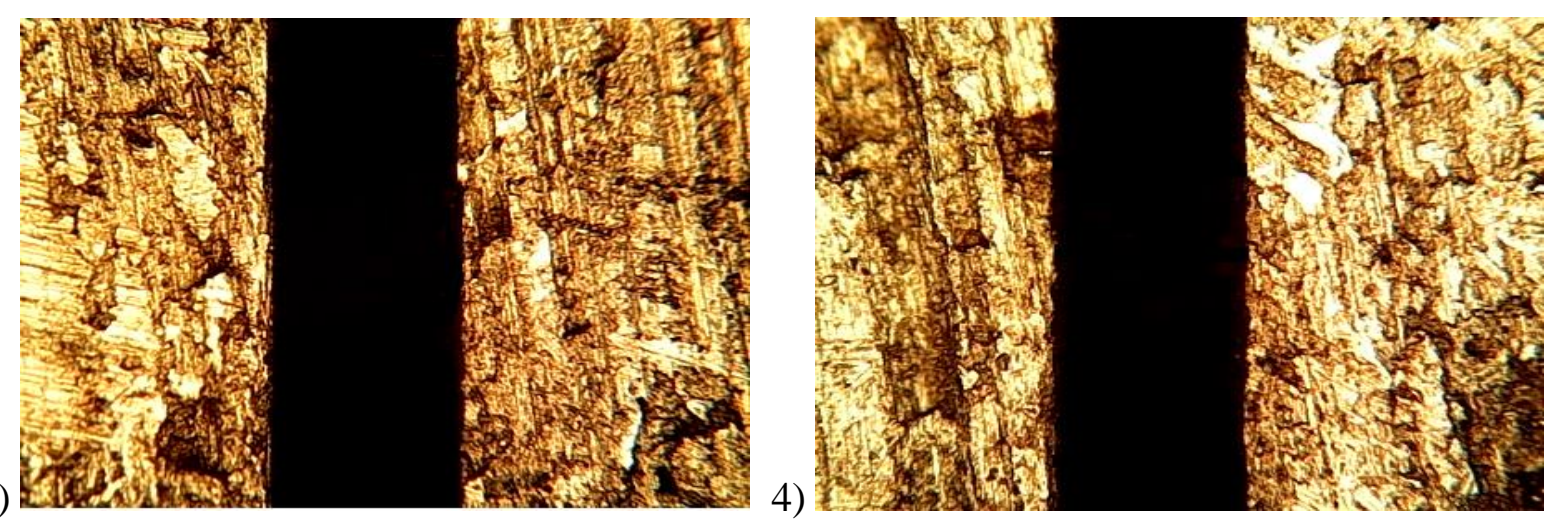

Fig. 2 K-width in tests 1 to 4,1 ) Test $1 ; \delta=0.342 \mathrm{~mm} ; 2$ ) Test $2 ; \delta=0.339 \mathrm{~mm} ; 3$ ) Test $3 ; \delta=$ $0.338 \mathrm{~mm}$; $)$ Test $4 ; \delta=0.334 \mathrm{~mm}$; (current $=5 \mathrm{~A}$, wire speed $=5 \mathrm{~m} /$ minute, wire tension $=$ $1.3 \mathrm{~kg}$, and voltage $=60$ volts).

\section{$3 \quad$ Results and discussion}

\subsection{K-width}

Figure 3 displayed that K-width increases, as the feed-rate of machine decreases. Test with smaller feed rate provide greater K-width. Kodalagara et al. [23] doesn't suggest the utilization of large feed-rate since it created higher irregularities in the K-width.

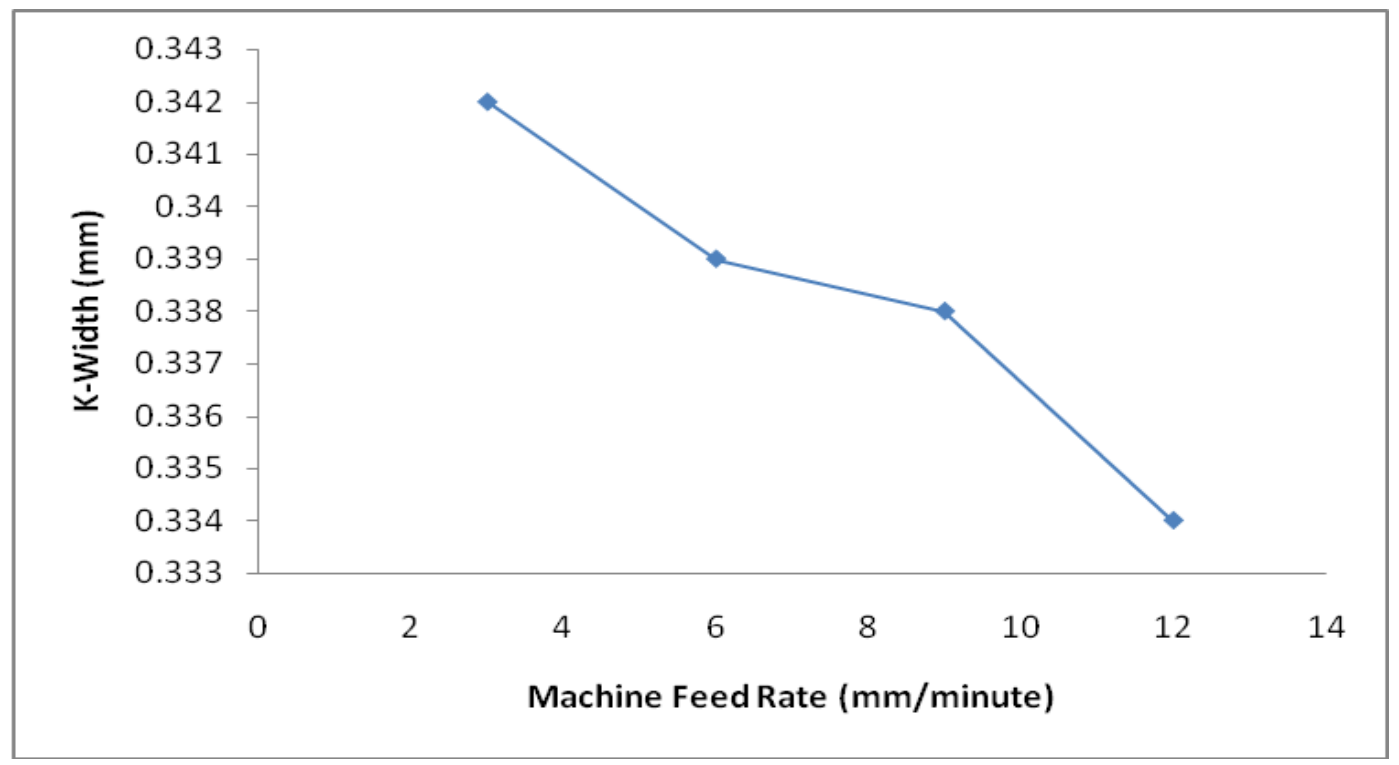

Fig. 3 Influence of machine feed rate on K-width

\subsection{Material Removal Rate (MR-R)}

Figure 4 displayed that MR-R increases, as the feed rate of machine increases. Test with smaller feed rate provide lesser MR-R. This outcome shows a similar example with Kodalagara et al. [23]. This is occurred in light of the fact that at the greater estimation of feed rate creates the closer space between the wire-cathode and the workpiece. The erosion of material is impacted by the spark energy. As feed-rate rises; MR-R likewise enhances till it arrives at optimal level. The MR-R declined with the declining of machine feed rate. 


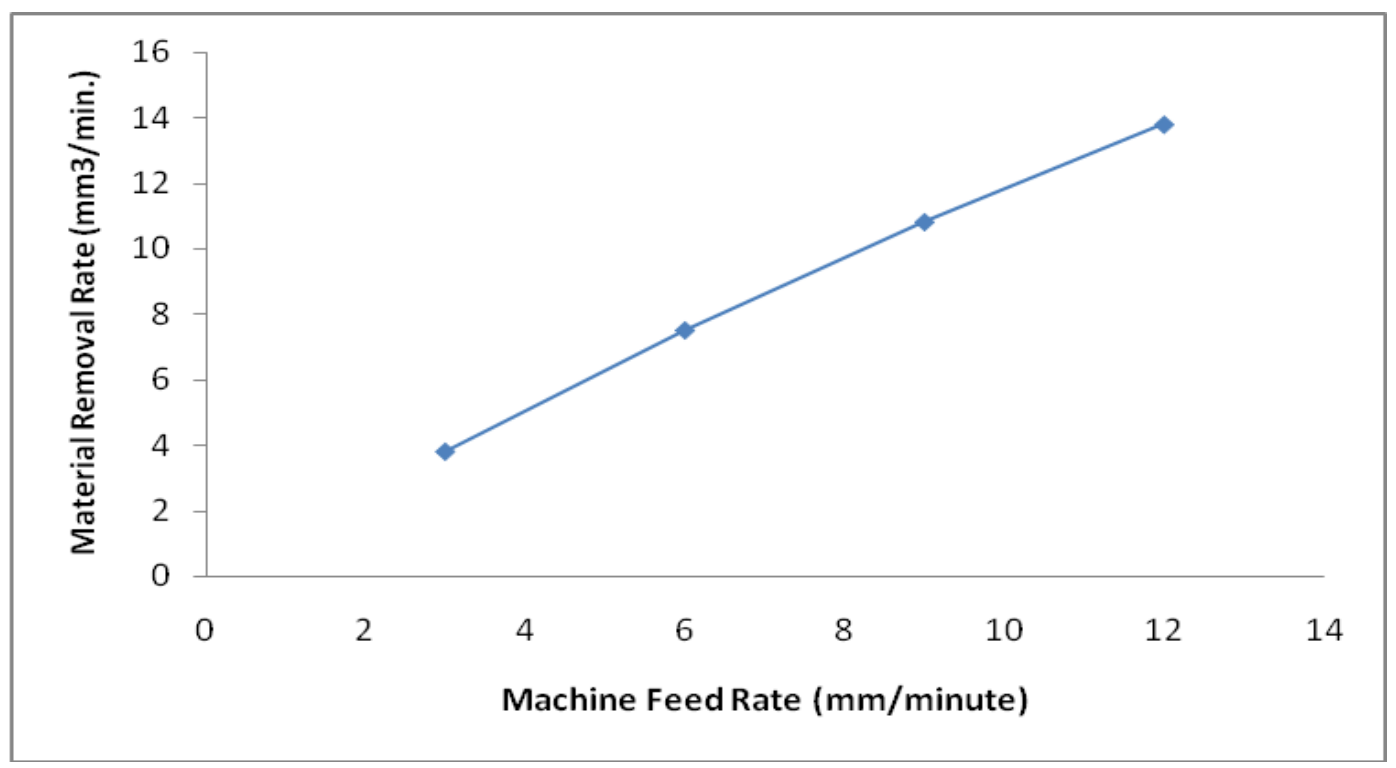

Fig. 4 Influence of machine feed rate on MR-R

\subsection{Surface-Roughness (S-R)}

Figure 5 displayed that $\mathrm{S}-\mathrm{R}$ increases, as the feed rate of machine increases. Test with less feed rate provide less $\mathrm{S}-\mathrm{R}$. This is happened because at the bigger value of feed rate causes the closer gap among the wire electrode and the $\mathrm{Al} / \mathrm{SiC}$ work-piece. Rao et. al. [24] referenced that, tension of wire and gap voltage of spark is seen as noteworthy factors in acquiring good finish of surface. This is happened because of the rise in tension of wire lessens its vibration and enhances the finish on the surface of machined component.

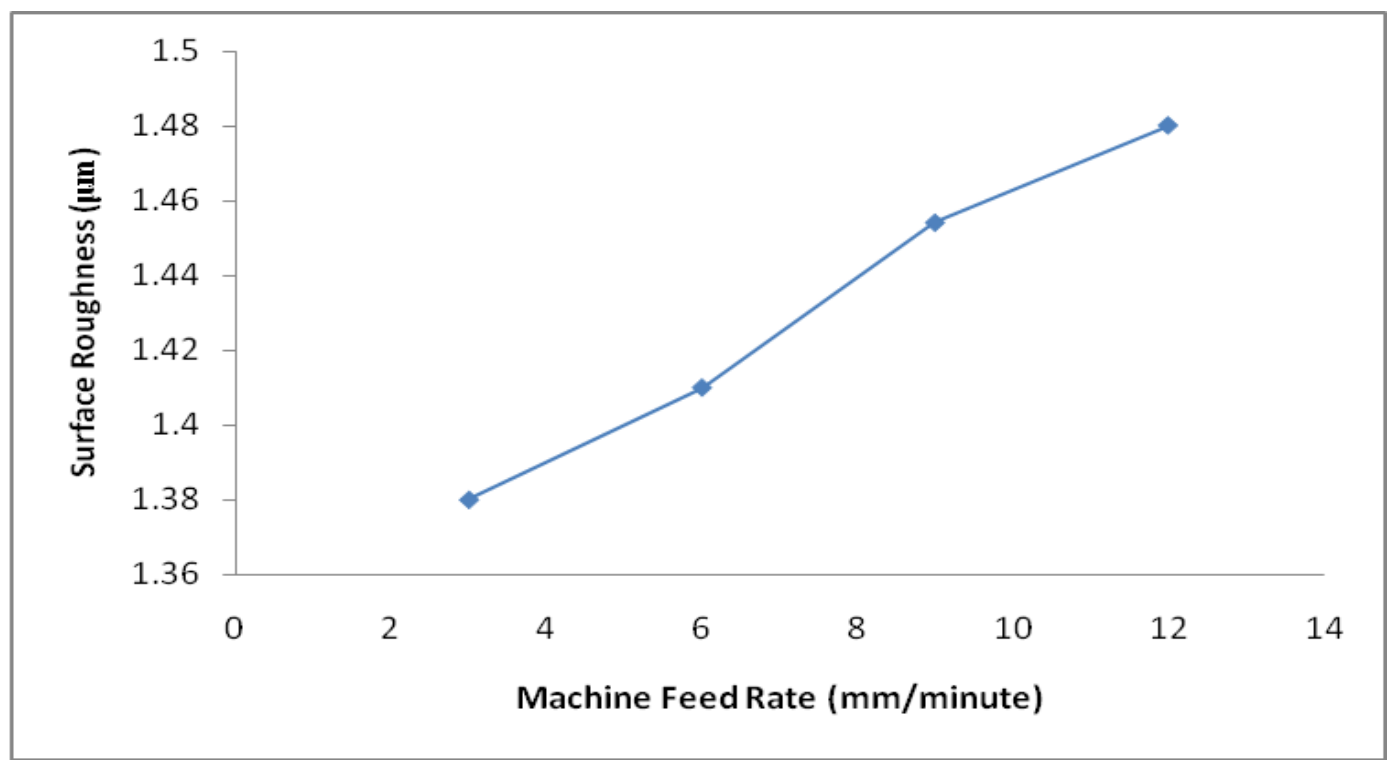

Fig. 5 Influence of machine feed rate on S-R

\section{CONCLUSIONS}

The following conclusions could be drawn based on the examination of kerf width images of machined work-piece, and understanding of figures from 3 to 5.

In machining of $\mathrm{Al} / \mathrm{SiC}$ composite through $\mathrm{W}-\mathrm{EDM}$ : 
1. The kerf-width increases with the decrease in feed rate of machine.

2. The MR-R increases with the rise in feed rate of machine.

3. The surface roughness rises with increase in machine feed rate.

4. The MF-R has been demonstrated to play a significant role in this experimentation work.

5 . Test 1 (current $=5 \mathrm{~A}$, wire speed $=5 \mathrm{~m} /$ minute, wire tension $=1.3 \mathrm{~kg}$, feed rate $=3$ $\mathrm{m} /$ minute, and voltage $=60$ volts) provides the larger K-width, better surface finish, and lesser MR-R.

\section{REFERENCES}

[1] Stavitskii, I. B. "Electrophysical and electrochemical methods of material processing", Nauka Obraz., no. 10, 2004. http://technomag.edu.ru/doc/46142.html.

[2] Ablyazm, T. R., Khanov, A. M., Khurmatullin, O. G. "Sovremennye podkhody i tekhnologii elektroerozionnoi obarabotki materialov (Modern Approaches and Technologies of EDM Processing of the Materials)", Perm: Perm. Nats. Issled. Politekh. Univ., 2012.

[3] Ho, K. H., Newman, S. T., Rahimifard, S., Allen, R. D. "State of the art in wire electrical discharge machining (WEDM)", International Journal of Machine Tools and Manufacture 44, pp. 1247 - 1259, 2004. DOI: 10.1016/j.ijmachtools.2004.04.017

[4] Sadiq, M. A., Rahman, M., Lim, H. S. "Study of WEDM parameter phenomena for micro fabrication", International Journal of Manufacturing Technology and Management 13 (2-4), pp. 226 - 240, 2008, DOI: 10.1504/IJMTM.2008.016773

[5] Miller S. F., Kao, C. C, Shih, A. J., Qu, J. "Investigation of wire electrical discharge machining of thin cross-sections and compliant mechanisms". International Journal of Machine Tools and Manufacturing 45, pp. $1717-1725$, 2005, DOI: https://doi.org/10.1016/j.ijmachtools.2005.03.003

[6] De, D., Nandi, T., Bandyopadhyay, A. "Parametric study for wire cut electrical discharge machining of sintered titanium", Strojnícky časopis - Journal of Mechanical Engineering 69 (1), pp. 17 - 38, 2019. DOI: https: 10.2478/scjme-2019-0002

[7] Raturi, H. P., Prasad, L., Pokhriyal, M., Tirth, V. "An estimating the effect of process parameters on metal removal rate and surface roughness in WEDM of composite AL6063/SIC/AL ${ }_{2} \mathrm{O}_{3}$ by Taguchi Method”, Strojnícky časopis - Journal of Mechanical Engineering 67 (2), pp. 25 - 36, 2017. DOI: 10.1515/scjme-2017-0015

[8] Lal, S., Kumar, S., Khan, Z. A., Siddiquee, A. N. "Wire electrical discharge machining of AA7075/SiC/A12O3 hybrid composite fabricated by inert gas-assisted electromagnetic stir casting process", Journal of the Brazilian Society of Mechanical Sciences and Engineering 36, pp. 335 - 346, 2014. DOI: 10.1007/s40430-013-0087-x

[9] Hemalatha, K., Venkatachalapathy, V. S. K., Alagumurthy, N. "Surface Integrity analysis in Wire-Cut Electric Discharge Machining of Al 6063/A12O3 Metal Matrix Composite through Response Surface Methodology", International Journal of Scientific \& Engineering Research 5 (12), pp. 104 - 110, 2014.

[10] Satishkumar, D., Kanthababu, M., Vajjiravelu, V., Anburaj, R., Sundarrajan, N.T., Arul, $\mathrm{H}$. "Investigation of wire electrical discharge machining characteristics of Al6063/SiCp composites", The International Journal of Advanced Manufacturing Technologym 56, pp. 975-986, 2011. DOI: 10.1007/s00170-011-3242-5

[11] Meena, K. L., Manna, A., Banwati, S. S., Jaswanti. "Effect of wire feed rate and wire tension during machining of pr-Al-SiC-MMCs by WEDM", European Journal of 
Engineering and Technology, Vol.1 (1), pp. 1 - 13, 2013.

[12] Modi, M., Agarwal, G., Patil, V. "Study and analysis of Wire Electrical Discharge Machining and its process parameters", International journal of scientific \& technology research 8 (9), pp. 1144 - 45, 2019. DOI: http://www.ijstr.org/research-paperpublishing.php?month=sep2019

[13] Modi, M., Agarwal, G., Chaugaonkar, S. D. "Grey-WPCA Based parametricoptimization and modelling of chromium Powder Mixed Surface electro Discharge Diamond Grinding of Inconel 600 using RSM", Strojnícky časopis - Journal of Mechanical Engineering 69 (4), pp. 65 - 88, 2019. DOI: 10.2478/scjme-2019-0044

[14] Fard, R. K., Afza, R. A., Teimouri, R. "Experimental investigation, intelligent modelling and multi-characteristics optimization of dry WEDM process of $\mathrm{Al}-\mathrm{SiC}$ metal matrix composite", Journal of Manufacturing Processes 15 (4), pp. 483 - 493, 2013. DOI: 10.1016/j.jmapro.2013.09.002

[15] Madhavadev, P., Vijayan, K., Senthilkumar, M. "Development of Numerical Model and Comparison with the Analytical Model for Predicting the Wire Effects in Wire Electric Discharge Grinding”, Strojnícky časopis - Journal of Mechanical Engineering 68 (1), pp. 69 - 80, 2018. DOI: $10.2478 /$ scjme-2018-0007

[16] Gauri, S. K., Chakraborty, S. "A study on the performance of some multi-response optimisation methods for WEDM processes", The International Journal of Advanced Manufacturing Technology 49, pp. 155 - 166, 2010. DOI: /10.1007/s00170-009-2391-2

[17] Phate, M. R., Toney, S. B., Phate, V.R. "Analysis of Machining Parameters in WEDM of Al/SiCp20 MMC Using Taguchi-Based Grey-Fuzzy Approach”, Modelling and Simulation in Engineering, pp: 1 - 14, 2019. DOI: $10.1155 / 2019 / 1483169$.

[18] Modi, M., Agarwal, G. "Integrated Statistical Methodology for optimizing machining parameters in SiC Powder Mixed - EDDSG process to machine Ti6A14V", Materiali in Tehnologije / Materials and Technology Journal 53 (3), pp. 357 - 366, 2019. DOI: 10.17222/mit.2018.194.

[19] Modi, M., Agarwal, G., Patil, V., Khare, A., Shukla, S., Sankhala, A. "Modeling and Analysis of Turning Process on Lathe Machine by Taguchi and ANOVA Approach" International Journal of Scientific \& Technology Research 8 (10), pp. 1466 - 707, 2019. DOI: http://www.ijstr.org/research-paper-publishing.php?month=oct2019

[20] Modi, M., Agarwal, G., Patil, V., Bhatia, U., Pancholi, R. "Parametric Optimization in Drilling of Al-SiC Composite Using Taguchi Method" International Journal of Scientific \& Technology Research 8 (9), pp. 2019 - 22, 2019. DOI: http://www.ijstr.org/research-paper-publishing.php?month=sep2019

[21] Modi, M., Agarwal, G. "Powder Mixed Electro Discharge Diamond Surface Grinding Process: Modelling, Comparative analysis and Multi-output optimization using Weighted Principal Components analysis", SV-Journal of Mechanical Engineering 59 (12), pp. 735 - 747, 2013. DOI: 10.5545/sv-jme.2013.1146

[22] Modi, M., Agarwal, G. "Optimization of Electro-Discharge Diamond Surface Grinding Process Parameters with Multiple Performance Characteristics of Ti-6Al-4V using Grey-Taguchi approach", International Journal of Advanced Materials Research 622 623, pp. 14 - 18, 2012. DOI: 10.4028/www.scientific.net/AMR.622-623.14

[23] Kodalagara, P. S., Nottath, R., Jose, M. "Material removal characteristics of micro slot (kerf) geometry in $\mu$-WEDM on aluminium", International Journal of Advanced 
Manufacturing Technology 51, pp. 611 - 626, 2010. DOI: 10.1007/s00170-010-2645-z.

[24] Rao, P. S., Ramji, K., Satyanarayan, B. "A Prediction of Material removal rate for Aluminum BIS-24345 Alloy in wire-cut EDM", International Journal of Engineering Science and Technology 2 (12), pp. 7729 - 7739, 2010.

\section{Appendix A}

The following nomenclature is used in the paper:

ED-M

EDDSG

F-EA

GRA

HM-MCs

K-width

MF-R

M-MCs

MR-R

MRSNR

RS-M

S-R

$\mathrm{T}_{\text {off }}$

$\mathrm{T}_{\text {on }}$

VIKOR

W-EDG

W-EDM

WPCA

WSNR
Electrical Discharge Machining

Electro Discharge Diamond Surface Grinding

Finite Element Analysis

Grey Relational Analysis

Hybrid Metal Matrix Composites

Kerf Width

Machine Feed Rate

Metal Matrix Composites

Material Removal Rate $\left(\mathrm{mm}^{3} /\right.$ minute)

Multiple Response signal-to-noise Ratio

Response Surface Methodology

Surface Roughness $(\mu \mathrm{m})$

Off-time of pulse $(\mu s)$

Pulse-on-time $(\mu \mathrm{s})$

VlseKriterijumska Optimizacija I Kompromisno Resenje

Wire Electrical Discharge Grinding

Wire Electrical Discharge Machining

Weighted Principle Component Analysis

Weighted signal-to-noise Ratio 